\title{
PUBLIC HEALTH OFFICIALS.-THEIR CHARACTER AND RELATIONSHIP TO ONE ANOTHER AND TO THE COUNCILS THEY SERVE.
}

By J. H. GARRETT, M.D., D.P.H. and Barrister-at-Taw, Medical Officer of Heath of Cheltenham.

$\mathrm{W}^{\mathrm{n}}$

E need go no further back than to the passing of the Public Health Act, 1875, in making our estimate of present-day conditions. At that date public health work was comparatively new. Developments had been taking place, it is true, for a long time prior, and town had been following town in the adoption of special legal provisions, which were mostly summarised in this Act, and made of more general application. The Act was to some extent experimental, as all new legislation must be. Private liberties had to be treated with tender care, and as a matter of fact nobody exactly knew what was required either in the matter of powers or in that of officials. The local elective councils having been fixed upon as the executive bodies, and their ignorance in public health matters being to some extent appreciated, it was seen to be imperative that certain officers should be elected to assist them. But really few men possessed of the requisite education and experience were at that time available, and the best had to be done that could be done in this state of affairs. The medical man with the ordinary qualifications for general medical practice, appeared to be the one best suited to be the chief public health officer, or medical officer of health; and so it was enacted that each local council, or sanitary authority, should appoint a medical man to that office. It had become well recognised that the circumstances under which men live and carry on their avocations often give rise to obnoxious conditions, such as for long have been known under the name of nuisances. Some of these were injurious to health, and a free adoption of the term "nuisance injurious to health" was made in the Public Health Act, 1875, to indicate conditions that particularly required the attention of the sanitary authority, and its public health officials. The discovery of all "nuisances injurious to health" could hardly be made the duty of a man of the superior education and training of the medical officer of health, and the service of another class of person was clearly required, and was consequently arranged for, and he was the inspector of nuisances, his more modern metropolitan cognomen being sanitary inspector.

The power to prescribe the general duties of both medical officer 
of health and inspector of nuisances was left in the hands of the Local Government Board, and this department of the central Government issues a list of duties to each officer as he is elected to his post, with a reminding copy of the same from time to time. The Public Health Act itself seems to contemplate that the inspector of nuisances would act under the medical officer of health. The medical officer of health can exercise by special provision of statute all the powers of the inspector of nuisances, but many powers requiring special knowledge and judgment, based upon a superior education, are enjoyed by the medical officer and are not shared in by the inspector, which is as might be expected. In the list of duties supplied by the Local Government Board to the medical officer and inspector respectively, there are these marked differences: The leading duty of the medical officer of health is to advise the sanitary authority on all matters connected with the health of the district, and upon all points involving action by the sanitary authority. The duties of the inspectors of nuisance are not at all advisory. He discovers and reports conditions existing, and ascertains that orders to carry out necessary works are properly served and complied with. The advice of the medical officer of health depends upon his knowledge of the matter in hand. He is ordered to keep himself informed of all influences affecting the bealth of his district, and to that end to keep it under inspection constantly; and it is inferred, though not expressly stated, that the information gained by the inspector of nuisances is to be available for the use of the medical officer of health. In fact it is quite imperative for the inspector to report to the medical officer everything he finds that can be considered detrimental to health, so that the latter may be able to form his estimate of what is required, and advise accordingly. It is equally necessary that the medical officer shall be able to command the inspector to do such things, and make such inspections, as in course of the performance of his duties may seem to be required by the medical oficer; for the latter must be possessed of all the information derived from such inspections if he is to advise upon it. In connection with his enquiries into the cause and prevention of infectious diseases, the medical officer must also be in a position to give the inspector such directions as he requires to be carried out, whether in respect of disinfection, or whatever else.

The list of duties issued by the Local Government Board states, that the medical officer of health shall superintend the work of the inspector of nuisances, in the way, and to the extent, that the sanitary authority shall approve and direct. The inspector of 
nuisances, on the other hand, shall submit himself to the medical officer of health according to the same direction. Such an undetermined relationship is well calculated to create difficulties between the officers.

It has been presumed that the members of the sanitary authority would of themselves take so great an interest in the way the work is to be done as to decide such a point as this, and to decide it correctly too. It is dangerous to leave anything so important to be settled by the local council. Members of a local council take a long time to come to a knowledge of the provisions of the Public Health Acts; in fact it is most rare for any member of a council ever to acquire a working knowledge of the law which he is supposed to administer. He is in perpetual ignorance of any order of the Local Government Board regarding the duties of the officers, and has but the vaguest idea of what these duties are. If the medical officer of Health calls his attention to the fact of its being necessary for him to say whether the inspector of nuisances shall act under his orders or not, he will express surprise that he should be called upon to settle such a matter, vote upon the moment the way he is led, and have forgotten all about it six months later. Very often he does not vote at all upon the subject for want of information and leading, the result being that the relationship between the officers remains unsettled.

There is consequently no singleness of command, but in its place unfriendly feelings and fallings-out amongst the officials. The writer can speak from experience of the easy working of a healthdepartment which has been put under the control of the medical officer of health, and in which there has never been the slightest question or hitch between the officers of the department during fifteen years of active performance of duties. There must be unity of purpose in every health-department, and to insure this there can be only one head officer, who, being the medical officer of health, certainly ought to be sufficiently master of the whole business to be easily able to maintain his position as head. In many districts there are more than one inspector of nuisances, and it is not possible for all to be masters.

The last order of the Local Government Board as to the duties of the inspector of nuisances appears to date from 1891, and is distinctly archaic, as is that also relating to the duties of medical officers of health. The indefinite relationship between the medical officer of health and the inspector of nuisances is not, however, the fault of the Local Government Board. The differences in the conduct 
of public health business to be observed in one place and another prevent any universally applicable list of duties being issued. A certain undesirable latitude and vagueness are demanded by the unfortunate irregularities that exist throughout the country. The fault lies rather in the law. There was neglect of a fundamental principle in the drafting of the Public -Health Act, 1875, in that no attention was paid to the necessity of having all the sanitary districts of the country of such suitable size and population as to enable them to be properly officered. The existing councils and boards of guardians were made the sanitary authorities, and great numbers of them were of too small an area and of too slight means to appoint officers to give their whole professional time to their official duties. The salary of the whole-time medical officer of health is more considerable than that of the inspector of nuisances, and whilst in certain districts the former officer has been engaged to give a small and indefinite part of his time to the duties of his post, the inspector of nuisances in the same district has been able to give more of his time, sometimes not being allowed to engage himself in other work. In such cases the inspector is the officer who has been chiefly available, and it has not been expedient to place him under the command of a medical officer of health who gives but little time and interest to his duties.

As it sometimes happens, under these circumstances, that the medical officer does not attend the council, it has also been necessary to provide for the inspector reporting direct to the council rather than to the medical officer of health, and to attend the council to explain his reports, a condition of things which has frequently led to his usurping the rôle of the superior officer. The position from the outset has consequently been most unsatisfactory, and the result, as we see it to-day, was courted by the failure of the Act to make workable arrangements, the base want having always been, as it is at this moment, a proper and fairly equal distribution of districts properly officered by experts giving their whole professional time to the duties. It appears that if the reform which is required be brought about, the creation of a new set of ruling councils, committees, or sanitary authorities will be imperative, whether these be formed by existing councils contributing members to a representative committee, to be fully empowered to act as sanitary authority, or otherwise. An alternative plan would be for the Local Government Board, in the absence of a board of public health, to administer the sanitary laws direct from London. Under any conditions of administration by the local council, the Central Board will need 
to exercise a closer control over local public health business, and particularly over local public health officers, than hitherto. The officers, at least, should be the officers of the Local Government Board, just as the factory inspectors are officers of the Home Office.

Seventeen years after the passing of the Public Health Act, 1875, an enactment required all future medical officers of health to districts of 50,000 population, or over, to obtain a diploma in " Public Health" or "State Medicine," it having by that time become patent that the ordinary medical training, whilst forming an essential background, was not sufficient to qualify the leading public health officer. The getting of the D.P.H., or B.Sc., in sanitary science, gives him more knowledge in theoretical hygiene, bacteriology, etc., but the real duties of the medical officer of health can only be learned in practice of the speciality, for which there exists by no means too much opportunity for the willing pupil before he enters upon the actual duties of the post to which he may be elected. There is at present a marked tendency for too many duties to be forced upon the medical officer of health. Whatever be his accomplishments, the main duties of the medical officer of health, even still, must be upon the lines laid down in the orders of the Local Government Board. His chief duty must be, as ever, to give advice and leading to his sanitary authority upon matters which are liable to affect the health of his district, and it is not well for his attention to be too greatly taken up with acting the part of physician to cases in the fever hospital, or that of public analyst in the chemical laboratory; neither should he allow himself to become too greatly absorbed in bacteriological work, in which it is possible to use up an immense amount of time and energy.

It is unfortunate from the point of view of practical advantage when the medical officer of health loses himself in some special enthusiasm, whether this be connected with the opsonic index, or Widal's reaction, or the taking of innumerable swabs from throats without any very definite object, the bacteriological estimate not causing any difference in the practical treatment. There is good to be derived from the sanatorium treatment of phthisis, but the work of closing houses unfit for habitation and providing better houses, the reduction of overerowding, and the betterment of conditions existing in workshops, are of even greater importance, and require the practical attention of the medical officer of health continually. The Local Government Board seems to have been remiss in allowing sanitary authorities to total up a minimum salary for the medical officer of health, by making him responsible for the performance 
of several distinct offices, and whilst he is attending to duties but little related to public health, his inspectors are vainly requiring him to lead and assist them. Without him their work becomes perfunctory; he must know what they are doing and how they are doing it, and be in constant communion with his chief inspector and often about with him. There are too many ways of being a medical officer of health at present, and it is requisite that the duties should be more clearly defined and regularised.

In any rearrangement of districts, which may before long take place, for the better administration of the sanitary laws throughout the country, the size and character of the districts will have to be carefully gauged to prevent them being under-officered. The duties of the medical officer of health must not be reduced to a broad supervision over a very large area; his practical and close assistance is required in the details of the work of the public health department. In large districts, where the work may easily become too much for one chief officer, there must be assistant medical officers of health. The Public Health Act, with a fine disregard to the limitations of the individual, makes provision for but a single officer, whatever be the size of the district. There is a vague reference to "such assistants, other officers and servants, as may be necessary and proper for the efficient execution of this Act," but one cannot see that any "assistant" appointed under this Act would be endowed with the powers of the medical officer of health, unless " in case of illness or incapacity" of the chief officer he were appointed deputy medical officer of health temporarily, such appointment being approved by the Local Government Board. Certain large towns have, however, been able to legally appoint an assistant, or permanent deputy medical officer of health, by means of powers conferred by a local Act.

The Local Government Board has shown itself as agreeable as it can be in approving the appointment of deputies and assistants ; but there is always a fatal tendency on the part of the local council, to adopt the minimum requirement whenever a minimum is fixed or suggested, as is the case in this question of officers. Because only one is mentioned in the Act, it is usually considered that only one is required.

The first-class inspector of nuisanees needs to be a man of no mean parts; and to thoroughly understand his business he requires a good technical education, as well as ample opportunity of seeing practical sanitary work efficiently and systematically carried out. A great number of men have now passed the examination of the Sanitary 
Institute, or those of the Sanitary Inspectors Examination Board; but one finds by experience that the holding of these certificates by no means guarantees a good inspector, though the compulsory education entailed in obtaining them is of no slight value, and the certificated man must always take precedence in theroetical knowledge of the uncertificated. It is personality that mainly tells. Those useful natural endowments of honesty in purpose and thoroughness in practice count more for value in the inspector, than the way he has acquitted himself in the examination room. The man in practice does not coincide with the man on paper invariably, which makes the choice of an inspector a rather chance proceeding. We want to read between the lines the evidence of a staunch character, a healthy energy and zeal for the performance of good work. What else is required is pretty sure to come, if not already present.

The character of the superior officer is effective upon all those who work under him. He gives the tone, and his example is apt to be followed, whether for good or ill. It is necessary for the inspector to find in his superior officer something to respect, and usually the latter has had such an advantage in education and the rest over the former, that this should follow. As a rule the medical officer of health must have a great advantage over the inspector in presenting matters to the committee or council of the sanitary authority. His position, status, education, address, usually assist him to exert a comparatively greater influence. His opinion is accepted with greater deference, and he is more effective in getting the vote passed for any required action. $H e$ is in a position to persuade, and a committee are sometimes almost constrained to adopt his suggestions because he is the paid expert; and if his advice be not taken, there ought to be somerational reason to show why not. The inspector of nuisances is not in a position to exert such influence, and although, as has been stated above, in many rural and small urban districts, the council see more of the inspector than of the medical officer, it is now recognised that sanitary administration is altogether defective in these districts, next to nothing ever being accomplished, and presumably a very necessary reform is pending, which will place the two officials in their proper position in relation to one another, and ensure the attendance of the medical officer of health at the meetings of the committee or council in whose hands the executive power lies. 